\title{
Priamele, przysłowia dialogowe i welleryzmy w kaszubskich zbiorach paremiograficznych
}

Aвstract: Pomierska Justyna, Priamele, przystowia dialogowe $i$ welleryzmy $w$ kaszubskich zbiorach paremiograficznych (Priamel, Proverb as a Dialogue and Welleryzm in Kashubian Paremiography). „Poznańskie Studia Slawistyczne” 8. Poznań 2015. Publishing House of the Poznań Society for the Advancement of the Arts and Sciences, pp. 125-136. ISSN 2084-3011.

The article presents special types of proverbs in Kashubian paremiography: priamel, proverb as a dialogue, welleryzm. These outstanding examples of the proverbial formulas are rarely recorded, usually known locally. The author found in the work of Ceynowa, Rudnicki, Lorentz, Sychta 21 priamels, 4 proverbs as a dialogue and several welleryzms. In addition to the characteristic building is significant that Kashubian priamels and welleryzms for the most part are thematically connected with relationships between man and woman.

KeYwords: proverb; priamel; welleryzm; Kashubian paremiology; Kashubian language; Florian Ceynowa; Fridrich Lorentz; Mikołaj Rudnicki; Bernard Sychta

Przysłowie ${ }^{1}$ przez większość rodzimych użytkowników języka rozpoznawane jest w mowie jako „mądrość ludowa”. W badaniach etnolingwistycznych zajmuje poczesne miejsce obok innych jednozdaniowych gatunków folkloru typu zagadka, rymowanka, anegdota² ${ }^{2}$ dla których kontekst tworzą realia rozmowy z towarzyszącym tłem pozawerbalnym. Jako zabawne podsumowania czy przerywniki stają się istotnym komponentem

${ }^{1}$ Kasz. przëstowié, ale lokalnie również dochlebié, przemówka (Sychta), gôdka (Ceynowa, Patock), prôwda (Derdowski), rzeklëzna (Labuda, Skwiercz), przëpòwiôstka (Labuda). Terminy te akcentują oralny sposób istnienia paremii i jej byt uzależniony od pamięci, tradycji. Na użytek własnych badań przyjmuję, że przysłowie to najczęściej lapidarne zdanie lub jego odpowiednik, które zawiera większość następujących cech: anonimowość, powszechność i trwałość, obrazowość, alegoryczność, zdolność do generalizowania i wartościowania, dydaktyzm.

${ }^{2}$ Antropologiczno-kulturowa koncepcja badań folklorystycznych znalazła swoje odbicie w zawartości i koncepcji budowy Słownika stereotypów i symboli ludowych (Bartmiński 1996: 22). 
dialogów i dowcipów językowych, nierzadko stanowią atrakcyjną puentę. Treściowo różnorodne, mogą być żartobliwe lub poważne, pouczające, czasem podają jakieś wskazówki postępowania; to samo wypowiedzenie może w różnych kontekstach mieć odmienny wydźwięk. Podczas rozmowy nie trzeba określać gatunku wyrażenia, interlokutor intuicyjnie wyczuwa „cudze słowo” i (także intuicyjnie) odbiera jego pochodzenie. Odnotowanie „mądrości” w zbiorze paremiograficznym lub odpowiedni kwalifikator w źródle leksykograficznym może przesądzić o genologii tekstu folkloru, nawet jeśli nie jest ona sensu stricto jednoznaczna. Trzeba zawierzyć badaczowi, który znał źródło zapisu.

Paremiografia kaszubska ma dość długie i bogate tradycje. Pjrszi tésac kaszébsko-słovjnskjch gôdk (1866) Floriana Ceynowy ${ }^{3}\left(\mathrm{CeyS}^{4}\right)$ zainspirował innych Kaszubów, na przykład w 1897 roku emigranci kaszubscy w Ameryce czytali Nórcyk kaszubści abò kòrëszk i jedna maca jãdrny prôwdë Hieronima Derdowskiego (Derd), a Max Pintus i Jan Patock publikowali swoje zbiory w materiałach folklorystycznych czasopisma towarzystwa ludoznawczego „Mitteilungen des Vereins für Kaschubische Volkskunde" (1908-1913, red. F. Lorentz, I. Gulgowski). Wiele przysłów zawierają słowniki jako egzemplifikacje użycia wyrazów: Gustawa Pobłockiego (1887), Stefana Ramułta (1893), Friedricha Lorentza (Lor). Druga połowa XX wieku przyniosła zapisy kaszubskich przysłów Leona Roppla w Nowej księdze przysłów $i$ wyrażeń przysłowiowych polskich (NKP, Roppel był korespondentem terenowym), a najobszerniejszy i najaktualniejszy zbiór ponad 4000 przysłów zawiera Słownik gwar kaszubskich na tle kultury ludowej Bernarda Sychty (Sy). Uporządkowanie scalonego 8-tysięcznego zbioru przysłów i ich wariantów (cf. Pomierska 2013) umożliwia przeprowadzenie badań pod kątem szczególnych typów formuły przysłowiowej. W obrębie znaczenia tego pojęcia należy rozpatrywać

${ }^{3}$ K.C. Mrongowiusz już w 1828 roku zwrócił uwagę m.in. na potrzebę zebrania przysłów kaszubskich, a F. Ceynowa odpowiedział na jego postulat w 1847 roku zbiorkiem około 60 przysłów (w XIX wieku niepublikowanym), cf. Treder 2006a, a w 1852 roku wydał 355 przysłów (na 495 numerowanych faktów paremiograficznych i frazeologicznych), cf. CeyO. Dla rzetelności wywodu trzeba odnotować także, że z zawierającego 1036 jednostek językowych różnego typu Pjrszégò tésąca..., wyodrębniłam ostatecznie 660 przysłów, pomijając wiele frazeologizmów, zawołań, zagadek, przyśpiewek itp., w których nie ma przewagi charakterystycznych cech przysłowia w myśl dzisiejszego naukowego rozumienia pojęcia.

${ }^{4}$ Rozwiązania skrótów źródeł paremiograficznych znajduje się na końcu artykułu. 
wyjątkowo interesujące, bo rzadkie gatunki przysłów - nieczęsto spotykane także w zbiorach ogólnopolskich, o czym pisali Krzyżanowski (1965), Świerczyńska (1974), Szpila (2001 i 2003) - priamele, przysłowia dialogowe i welleryzmy.

Dowodem formuliczności paremii jest prymarna ustna proweniencja, wyróżniające cechy składni, rym, zjawisko paralelizmu, kontaminacji i utrwalenia archaizmów, do tego jeszcze zastygłe w tych strukturach językowych sposoby obrazowania. Nierzadkie notowania kilku lub kilkunastu wariantów tego samego przysłowia są paremiograficznym potwierdzeniem formuliczności - nie uczenia się na pamięć, ale odtworzenia „mądrości ludowej” w nowym kontekście przez nowego nadawcę. Definicyjna lapidarność przysłowia wyraża nie tyle cechę ilościową, ile fakt, że nie zawiera ono zbędnych elementów, a żądaną treść opisuje w trafnie zestawionych słowach i obrazach. Formuliczność w takim wypadku spełnia funkcję mnemotechniczną i stylistyczną, co zauważyli badacze języka folkloru:

W poetyckim języku ludowym formuły nie tylko ułatwiają wykonawcy proces budowania tekstu, a słuchaczom odbiór, lecz są przede wszystkim skrótowym środkiem ekspresji. Nadają aprobowany społecznie, dobitny i poetycko zobiektywizowany kształt określonym i również typowym przeżyciom i sytuacjom. Odpowiadają przez to potrzebom twórczości zbiorowej, opartej na typizacji elementów formy i treści (Bartmiński 1973: 44).

Przez formułę przysłowiową należy rozumieć pewną stałą, powtarzalną, reprodukowaną jednostkę metryczno-leksykalno-semantyczną, syntaktycznie wystarczalną, używaną w dających się przewidzieć kontekstach i sytuacjach (Pomierska 2013: 306).

Priamele tworzą ciekawą strukturę semantyczną i syntaktyczną, bo konstrukcja tych przysłów polega na zestawieniu różnych elementów (minimum dwóch) i wskazaniu ich nieoczekiwanego podobieństwa (Świerczyńska 1974: 33); puenta wydobywa z przedmiotów lub zjawisk nieprzewidywaną cechę wspólną - dla porównania dwa warianty jednej paremii:

Kòt mùszi bëc łowny, a chtop mòwny (Ram 177).

Kòt łowny, a chłop mòwny nigdë nie zdżina (CeyS 19, cf. NKP II 164).

Paralelne zestawienie desygnatów kòt/chłop i ich określeń łowny/mòwny wyróżnia atrybuty porównywanych, ale w drugim przykładzie oprócz tego połączenia dodano wniosek, który wzmacnia cechy uwydatnione 
stylistycznie rymem i wzbogaca paremię treściowo. To charakterystyczna cecha priameli, które akcentują podwójnie: raz w koncepcie zestawień, drugi raz w konkluzji, stanowiącej swoistą klamrę i nierzadko jądro wysublimowanego dowcipu. Taka struktura formuły przysłowiowej odróżnia priamel od przysłów zawierających tzw. okresy trójdzielne ${ }^{5}$ (Krzyżanowski 1980: 146), w których trzy człony w wypowiedzeniu pojedynczym albo trzy zdania składowe wypowiedzenia złożonego współrzędnie zostały tak uporządkowane, że ów ostatni, trzeci składnik zawiera puentę, jak np.

Baran stôri, òwca młodô, jagniôk pewny (Sy VII 102).

Wóz òdpòcziwô òb zëmã, sanie òb lato, kón nawet niedzelë ni mô (Sy II 196).

Rôz nie je wiedno, dwa razë nie czãsto, trzë razë nie czãsteczno (Sy I 163).

Jak pùdzesz na wòjnã, pòmòdlë sã rôz, jak pòjachôsz na mòrze, pòmòdlë sã dwa razë, a jak sã bãdzesz żenit, nie zabãdzë trzë razë sã pòmòdlëc (Sy III 111).

W historycznych źródłach kaszubskich priamele występują nader rzadko, oprócz wyżej cytowanego o chłopie i kocie jeszcze dwa znajdujemy w pracach Ceynowy:

Młënarsczi swinie do chòwë, a ksãżi góspòdënie za żonã nie bierzë (CeyS 10).

Pòlsczi mòst, niemiecczi pòst, żëdowsczé nôbòżeństwò: to wszëtkò błazeństwò (CeyO 15).

Inne przykłady mają nowsze notowania, a oprócz analogii formalnych łączy je tematyka; większość kaszubskich priameli drwi z ułomności niewieściej.

Trzëmac biatkã za stowò, a rëbã za ògón to na jedno wëchôdô (Sy I 100). war. Wãgòrza za ògón, a białkã za stowò trzëmac - to jedno (Rop NKP II 89).

Czej norda zapadnie, a stôrô baba sã rozgôdô, tej ni ma radë (Sy III 215).

Białka i diôbét chôdaja jedna i ta sama droga (Sy I 100, oryg.).

Reny deszcz a stôri babë tuńc, to weznie snadnie kuńc (Sy IV 320).

Pòżezzka a strata to sq dwie sostrë (Sy V 174, oryg.).

Można podejrzewać, że twórcami tych prześmiewczych zestawień są mężczyźni, mężowie, którzy w ten sposób mogą w kontaktach towarzyskich krytykować żony (kasz. białka to m.in. kobieta zamężna); trzeba

${ }^{5}$ To nie są priamele ,z komentarzem wyrażonym implicite”, jak sugeruje Szpila (2003: 81-82), ponieważ brak im owego zaskakującego wniosku, który zwielokrotnia celowość zestawienia danych elementów. 
pamiętać, że zarejestrowany materiał związany jest z realiami dziewiętnastowiecznej wsi. Stereotypowo kobiety posądzane są o gadatliwość i towarzyszącą jej niedyskrecję, a występujący w dwóch przysłowiach przymiotnik stôrô (stara) został użyty dla podkreślenia poufałego stosunku do kogoś dobrze znanego, nie do określenia wieku.

Dodanie trzeciego porównywalnego elementu w sposób oczywisty wzmacnia koncept priamelu, ale liczba składników - mimo że w ogóle może dojść nawet do kilkunastu (Szpila 2003: 81) - w przysłowiu kaszubskim nie przekracza trzech. Potrójnie uszeregowane desygnaty z komentarzem silnie spaja rytm, rym (nierzadko wewnętrzny, między leksemami wyliczenia, bardzo częsty na końcu wyliczenia i puenty) i linia intonacyjna wypowiedzenia, np.

Białczi, kònia i brzëtwie sã nie pòżiczô (Sy I 100, NKP II 1048).

Pòrénczny deszcz, dzéwczëca górz i stôri babë tuńc robia wnet kùnc (Sy I 204, NKP I 421).

Nipòcô białka, nipòcy sq̨sôd, a diôbét trzecy, to jedny matczi dzecë (Sy I 100, NKP III 961).

Lës (= rudy), zéz i diôbét trzecy, to jedny matczi rodzoné dzecë (Sy II 357, cf. NKP III 858).

Psowi, kòniowi a chłopù, tim ni mòże nigdë wierzëc (Sy IV 260, cf. NKP II 679).

Z rëbôka, mëslëwégò i mtënôrza nie bãdze dobrégò gòspòdôrza (Rop NKP I 711) ${ }^{6}$.

Ciekawy efekt stylistyczny nastąpi, kiedy dopowiedzenie, które miało być zaskakującą puentą, poprzedzi wyliczenie. Dzięki odwróconemu szykowi wypowiedzenie nabiera charakteru refleksyjnego, co widać w przykładzie o zmienności niewieściej i prawdzie, która mija się z prawdą:

Te trzë rzeczë sa wiedno zmienné: łaska pańskô, serce białogłowë i pògòda jesénnô (CeyS 14),

cf. war. Łaska pańska, gust kobiet, pogody jesienne - wszystko to odmienne (NKP II 788).

To je takô prôwda, że co slepi ùzdrzôt, głëchi zaczut (= zasłyszał), to niemi dali òpòwiôdô (Sy V 73, cf. NKP III 431 [ale tu bez znamiennego początku]).

Podane wyżej przykłady priameli to skończony zbiór w obrębie Księgi przysłów kaszubskich (cf. Pomierska 2013). Rzadkość występowania tego

${ }^{6}$ W NKP I 711 gospodarz 41c są trzy notowania: Adalberga, Świerkosza (1930) i Roppla; trudno jednoznacznie orzec o kaszubskiej proweniencji tego zapisu. 
gatunku w zbiorach paremiograficznych dowodzi - w moim przekonaniu kunsztowności struktury syntaktycznej tego typu przysłów, a także trudności adaptacyjnych natury semantycznej, na które napotykały te szczególne zestawienia, wędrując między rejonami geograficznymi i kulturowymi. Tym bardziej warto wyodrębnić oryginalne w zbiorze kaszubskim priamele, notowane tylko przez Sychtę, które świadczą o produktywności tego typu formuły przysłowiowej w mowie Kaszubów:

Brzózka, wierzba i dana sa w stużbie ù niebiesczégò Pana - o roli brzozy, wierzby i choinki na Boże Ciało, Niedzielę Palmową i Gwiazdkę (Sy I 80).

Cebùla, tëczk (= szczypiorek) a piotrëszka to je strëchòwskô (= żebracza) òbòna (= okrasa) - o ubogim w mięso posiłku (Sy V 177).

Mogą one także występować w formie refleksji poprzedzającej potrójne wyliczenie:

Mie tak wiedno szło, rôz w bótach, rôz na żokach (= w skarpetkach), rôz bòso (Sy VI 310).

Piéń trzë razë grzeje: rôz, jak gò sã kòpie, drëdżi rôz, jak gò sã rąbie, a trzecy rôz, jak sã nim piéck pôli (Sy IV 250).

Szczególnym dowodem produktywności może być fraza wyekscerpowana z międzywojennej literatury kaszubskiej: „Dzeùsa serce, żôłądk swini, czełbasë wnãtrznoscë fùl nôwrotnoscë" (nôwrotnoscë - kaprysów), choć w jej rodowodzie możliwe jest inne źródło niż ustna proweniencja (Budzisz 2007: 55) ${ }^{7}$, bardzo prawdopodobne jest gwarowe pochodzenie, cf. „Wiele sierści na jałowej krowie, tyle złości, przewrotności w mężatce i wdowie" (NKP II 438, Kolbeg).

Na pograniczu przysłów i anegdot sytuują się przysłowia dialogowe, które w pełnej formie składają się z kilku zdań - replik w dialogu, bez elementów opisowych i interpretacyjnych. Najczęściej podaje się następujący przykład: „Babko, dzwonią do kościoła. - Bolą mnie nogi. - Babko, grają. - A gdzie moje chodaczyska, trzeba ruszyć do karczmiska" (Szpila 2003: 75, inny war. Krzyżanowski 1980: 48). Były one popularne w osiemnastowiecznej Europie, w Polsce rzadkie, a badacze języka kaszubskiego zapisali właściwie tylko cztery przykłady.

${ }^{7}$ Polonizmy we frazeologii Alojzego Budzisza (1874-1934) stwierdził Jerzy Treder (1986: 108). 
Najciekawsze jest przysłowie - w polskich zbiorach nienotowane, a w trzech kaszubskich źródłach występujące aż w pięciu wariantach! które można odczytywać jako szczególną metaforę stałości i zmienności (trwania i przemijania), odmiennej natury różnych zjawisk i związanych z tą odmiennością nieporozumień albo ludzkiego niepotrzebnego (wścibskiego) wtrącania się w cudze sprawy. To dialog rzeki przepływającej przez łąkę lub obok niej:

Rzéka szła herunter (= w dół), a ta łąka pita rzéka: - Òkrãglëca, gdzė̇ të biegôsz? A ta rzekła: - Òstrzëglëca (= łąka skoszona, tylko w przypowieści), cëż të chca ò to? (Rud 165).

A ta łąka rzekła do ti wòdë: - Biegùna, gdzeż të biegôsz? A ta wòda zôs rzekła do ti łączi (na bëła zesektô): - Òstrzëglëca, cëż të chca ò tô [ò tegò] (Rud 183).

Òstrzëglëca pita wodã: - Biegùna, gdzeż të biegôsz? Wòda rzekta: - Òstrzëglëca, cëz të chcesz òd tô? (Lorentz 1934: 113).

Òstrzëglëca pitała sã rzéczi: - Gdzeż të biegôsz, òparzonô? - Rzéka rzekła: Co tobie do tegò (Sy III 345).

Łąka pitô rzéczczi: Gdzeż të jidzesz, krzëwòległô (= rzeko)? - Co të chcesz, rôz w rokù strzëgłô? (Sy II 274).

Ostatni przykład wyróżnia się ,nowoczesnym” kształtem językowym: w paralelnie zbudowanych odpowiedziach dialogowych jest równa liczba sylab, akcent pada na ostatnie słowo (wzmocnienie rymem) będące w obu przypadkach przydomkiem nadanym żartobliwie lub złośliwie. Wszystkie warianty pochodzą z północnych Kaszub (w źródłach znajdują się odpowiednie uwagi geograficzne), trzy pierwsze najprawdopodobniej z najdalszego krańca, tj. od Słowińców.

Słowińcy jako Pomorzanie-Kaszubi zamieszkiwali okolice jezior Gardno i Łebsko, najbardziej na północny zachód wysunięty kraniec Kaszub i Słowiańszczyzny i stanowili - z powodu silnie zgermanizowanego otoczenia - nader ciekawy obiekt badania językowego. W połowie XIX wieku Pomorze Zachodnie było już mocno zgermanizowane, ale oddalone od większych miast błotniste okolice między jeziorami odstraszały kolonistów niemieckich. We wsiach Smołdzino, Gardna i Kluki żyli Kaszubi, którzy znali swą słowińską mowę, choć relacje z podróży kolejnych uczonych (na przykład Aleksandra Hilferdinga) dowodzą stopniowego zanikania tego dialektu kaszubskiego.

Mikołaj Rudnicki z Poznania w 1911 roku na zlecenie Akademii Umiejętności w Krakowie podjął się weryfikacji wydawanych w pierwszej 
dekadzie XIX wieku opracowań języka Słowińców autorstwa Friedricha Lorentza (gramatyka, teksty, słownik), a wyniki swoich badań opublikował w artykule w roku 1913 (Rud), podając zapisy przytoczonych przysłów. Friedrich Lorentz, oprócz wskazanej wyżej publikacji i Słownika pomorskiego (Lor), przygotował także Zarys etnografii kaszubskiej, w którym ludową twórczość słowną definiował następująco: „Zaliczymy tu zwroty obrazowe, przysłowia, zagadki, nieśpiewane rymy i sentencje, pieśni, podania i baśni”" (Lorentz 1934: 111). To właśnie tu, a nie w Pomoranisches Wörterbuch, zamieścił podany powyżej przykład przysłowia dialogowego, co uzasadniałoby jego słowińską proweniencję. Stąd mógł je znać także Sychta (jego słownik wydawany był w latach 1967-1976), który sprawdzając znajomość wśród Kaszubów tego anachronicznego w pierwotnych zapisach dialogu łąki i rzeki, zanotował modyfikację trochę upodobniającą paremię do zagadki. Różnice leksykalne występujące w poszczególnych wariantach są najlepszym potwierdzeniem siły działania formuły przysłowiowej w odizolowanej enklawie językowej.

Każdy z wymienionych eksploratorów podaje jeszcze jeden odrębny przykład przysłowia dialogowego:

Ten las rzekt do żabë: Gdzė të, grablëjca (= leziesz), sã tu toklëjesz (= męczysz)? A żaba: - Gabë (= żeby) të rzekt mili (= lepiej): Dobri dzéń, frejlina (= panno)! (Rud 165).

Żaba pita lësa: - Gãsarzu (= gęsiarku; fig. o lisie), gdzeż të jidzesz? - Lës rzekt do żabë:

Të stôrô krupana (= ?), cëż të sã môsz za tim do pitaniô? (Lorentz 1934: 113).

Tak je głupi, że nawet kòzé ògòna nie pòtrafi zawiãzac. - Jô bëm téż nie pòtrafit (Sy V 377).

To wszystkie przysłowia dialogowe w kaszubskich źródłach pisanych. Friedrich Lorentz w Zarysie etnografii zwraca szczególną uwagę na przysłowia przykładowe (termin Lorentza):

jak się zdaje, mało znane u Kaszubów, spotykamy je tylko u Słowińców i Kaszubów północnych, np. Tidzén sã pòcząt dobrze! - rzekt knôp (= chłopiec) a dostôł w pòniedzôłk reno bicé; Biada temù, co na romni (= odkrytym) jesta! - rzekt lës a sedzôł za barna (= broną); Lepszi kap jak dëcht cek - rzekt lës pòd bróną. Najwidoczniej zaznacza się tu wpływ dolnoniemiecki (Lorentz 1934: 112).

Przysłowiem przykładowym nazywa Lorentz tę formę, którą paremiolodzy współcześni - za A. Taylorem The Proverb (1931/1985) - zwykli 
nazywać ponadnarodowo welleryzmem (Szpila 2003: 75). Lorentz, wychowany w niemieckim kręgu kulturowym, w którym zapewne panowała moda na taki sposób konstruowania dowcipu, który z czasem przechodził w przysłowie, był szczególnie wyczulony na obecność znanej formuły słownej (przysłowiowej) w wypowiedziach swoich informatorów.

Welleryzm ma charakterystyczną kompozycję, jest to wypowiedź (nierzadko nawet przysłowie, częściej utarte powiedzenie albo znany cytat) włożona w usta jakiejś konkretnej osoby lub osadzona w określonych okolicznościach, co daje zaskakujący, najczęściej dowcipny efekt. Poniżej znajdują się zestawienia, kiedy wypowiedź jest przysłowiem.

1. Przysłowie znane także na Kaszubach, poza Kaszubami notowane tylko jako komponent welleryzmu:

Wiôldżi krzik a môti strzig (= strzyżenie) (Sy V 186).

Dużo krzyku, mało wełny - mówił diabeł strzygac świnię (NKP II 221).

(ang.) Much noise and little wool, said the devil and sheared a pig (cyt. za: Szpila 2003: 76).

(niem.) Viel Geschrei, wenig Wolle, sagte der Teufel und schor eine Sau (cyt. za: Szpila 2003: 76).

2. Jeden z wariantów kaszubskiego przysłowia jest welleryzmem nienotowanym w NKP:

Gdze wiele głów, tam wiele rozëmów (CeyS 3, cf. NKP I 637).

Wiele głów, tëlé rozëmów (/zdań) (Sy V 340, VI 199 [podobnie na Kociewiu]).

Jim wicy głów, tim wicy słów (Rop NKP I 638).

Wiele głów, wiele rozëmów - rzekt gbùr i skùlnąt kapùstã z górë na dót (Sy II 134 Puzdrowo).

3. Przysłowie jest komponentem aż dwóch wariantów welleryzmu nienotowanego w NKP:

Swój swégò znaje (CeyS 13 i NKP III 362).

Trafit swój na swégò - rzekt diôbét do kòwôla (CeyS 11, Lor I 423, Sy II 211).

Pòtkôt swój swégò - rzekt diôbét do kòminiarza, czej sã òbaj zeszlë (Sy II 194 pn).

Najczęściej jednak dialogowym komponentem welleryzmu jest stwierdzenie, które samo w sobie mogłoby być konkluzją, refleksyjnym lub dydaktycznym podsumowaniem w rozmowie, przy czym intencją nadawcy jest humorystyczny wydźwięk riposty. Sentencjonalnie mogłyby zostać 
odebrane konstatacje: „To nie je tak letkò głową robic” (cf. główka pracuje, pracować głową), „Mòje ùczinczi jidą za mną (bibl.)”, ale w zestawieniu z drugą częścią paremii otrzymujemy zgoła odmienny efekt:

To nie je tak letkò głowa robic - rzekt gbùr do ksãdza. Jô to widzã pò swòjich wòłach (Sy I 314 Sierakowice).

Mòje ùczinczi jida za mna - rzekł bednôrz. - W tim rozwalëła sã beczka (Sy VI 9).

Z kaszubskich oryginalnych welleryzmów można by ułożyć interesującą rozmowę, w której kolejnym zmianom interlokutora towarzyszy zmiana stanowiska w sprawie osoby dominującej w małżeństwie:

Wszëtkò robi sã za miara - rzekt krôwc i narżnąt biatce tokcã (= miara) (Sy IV 373).

Le sã nie wdawôj w niżódna bitwã! - rzekła białka do chłopa i rżnãła gò w teb (Sy I 111).

Terô mòżesz jic do Stôrégò Frëca (= Fryderyk II) na ùżalenié - rzekt chtop białce, czej òn ji narżnąt (Sy I 287).

Wszësczé gòdzënë nie są szczeslëwé - rzekt chłop i nabił babie (Sy II 39).

Natomiast o samym cudzołóstwie można przecież powiedzieć: „Człowiek sã mòże milëc - rzekł chłop. - To bëło cemno, tak jô mëslôł, że to bëła mòja białka" (Sy II 39). Co poradzi matka córce, gdy ta zwierzy się jej ze swoich kłopotów? „Gãs mùszi gąsora słëchac, a të bë chłopa nie słëcha! - rzekła matka do córczi, czej córka przëszła do ni na ùżalenié..." (Sy I 313).

Cytowane welleryzmy to prawdziwe perełki w kaszubskich zbiorach paremiograficznych, a te związane z relacjami małżeńskimi wykazują największą frekwencję. Stanowią zwięzłą rekonstrukcję anegdoty, poddają się łatwo różnym zabiegom aktualizującym i w ten sposób dostosowują detale konkretnej sytuacji do potrzeb użycia. Są dowcipne, więc z pewnością jowialny Kaszuba (rzadziej Kaszubka) spuentował za ich pomocą niejedną dramatyczną sytuację domową. W polskiej paremiografii występują rzadko, a ich stosunkowo duża liczba na Kaszubach - choć notowane są tylko przez Lorentza (Lorentz 1934: 112), który dopatrywał się w ich występowaniu wpływu dolnoniemieckiego i w Słowniku Sychty (cf. zestawienie Treder 2000: 190-192) - dowodzi wyjątkowego poczucia humoru mieszkańców Pomorza, o których mówią: „I mrëk sã czasã rozgôdô” - bo „Kaszëba mô cwiardą mòwã, ale mitczé serce”. 
Wyróżniające się gatunki przysłów, stanowiące przedmiot zainteresowania w niniejszym artykule: priamele, przysłowia dialogowe i welleryzmy doczekały się kilku opracowań, stąd nietrudno ustalić miejsce tej grupy przysłów kaszubskich na tle paremiografii polskiej. Specyficzna struktura językowa - otwarta na humor, żart, dowcip, przytyk, ironię okazała się niezwykle produktywna w kręgu tematycznym związanym z kontaktami damsko-męskimi, a ściślej: małżeńskimi. Przykłady wykorzystane do zobrazowania zagadnienia wyróżniają się rzadkością występowania i jednokrotnością notowań (wyjątek: przysłowie dialogowe z rzeką i łąką!), ale podobne uwarunkowania występują w zbiorach polskich, w których formy te także uchodzą za rarytas.

\section{Wykaz skrótów}

CeyO - F. Ceynowa, 1852, Przestovjo kaszebskie, w: Образцы кашебскаго наречія. Памятники и образцы народнаго языка и словесности (Изданіе II-го Отде̌ленія Императорской Академіи Наукъ), Тетрадь 1, листь 6, Санкт Петерсбург, с. 93-112.

CeyS - F. Ceynowa, 1866, Pjrszi tésac kaszébsko-stovjnskjch gôdk, w: F. Ceynowa, Skôrb kaszébsko-stovjnskjè mòvé, z. 1-13, Świecie.

Derd - J. Derdowski, 2001 [1897], Nórcyk kaszëbsczi abò kòrëszk i jedna maca jãdrny prôwdë. Pòzbiérôł Méjster òd piesni, Ò panu Czôrlińsczim co do Pùcka pò secë jachôt. Drëkòwôł Jarosz Derdowsczi we Winonie w Nórtowi Americe 1897, ùrëchtowôł i pòsłowié napisôł J. Tréder, Gduńsk.

Lor - F. Lorentz, 1958 [1933], Pomoranisches Wörterbuch, Bd. I: A-P, Berlin.

NKP - J. Krzyżanowski (red.), 1969-1978, Nowa księga przystów $i$ wyrażeń przystowiowych polskich; na podstawie dzieła S. Adalberga, t. 1-4, Warszawa.

Ram - S. Ramułt, 2003, Stownik języka pomorskiego, czyli kaszubskiego, scalił i znormalizował J. Treder według wydań Akademii Umiejętności z roku 1893 i Polskiej Akademii Umiejętności z roku 1993, Gdańsk.

Rop - L. Roppel, [1955], Przystowia kaszubskie, rps, Archiwum NKP.

Rud - M. Rudnicki, 1913, Przyczynki do gramatyki i stownika narzecza stowińskiego,

Materiały i Prace Komisji Językowej AU w Krakowie, t. 4, Kraków, s. 1-245.

Sy - B. Sychta, 1967-1976, Stownik gwar kaszubskich na tle kultury ludowej, t. 1-7, Wrocław. 


\section{Literatura}

Bartmiński J., 1973, O języku folkloru, Wrocław.

Bartmiński J., 1996, O „Stowniku stereotypów i symboli ludowych”, w: Stownik stereotypów i symboli ludowych, t. 1, Kosmos, red. J. Bartmiński, Lublin, s. 9-34.

Budzisz A., 2007, Dokôzë, zebrôł ë zrëchtowôł R. Drzéżdżón, Gdyniô.

Krzyżanowski J., 1965, Przystowie, w: J. Krzyżanowski, Stownik folkloru polskiego, Warszawa 1965, s. 334-341; przedruk: J. Krzyżanowski, Szkice folklorystyczne, t. 3, Wokót legendy i zagadki. Z zagadnień przysłowioznawstwa, Kraków 1980, s. $39-57$.

Lord A.B., 1975, O formule [rozdz. 3, The Singer of Tales, Cambridge 1964], „Literatura Ludowa" nr 4-5 (19), s. 62-75.

Lorentz F., 1934, Zarys etnografji kaszubskiej. Rozprawa z pracy zbiorowej, w: A. Fischer, T. Lehr-Spławiński, F. Lorentz, Kaszubi. Kultura ludowa i język, „Pamiętnik Instytutu Bałtyckiego", t. 16, red. J. Borowik, s. 1-139.

Pomierska J., 2013, Przystowia kaszubskie. Studium z paremiografii i paremiologii, Gdańsk.

Szpila G., 2001, Rzecz o polskich priamelach, „Literatura Ludowa” nr 1 (45), s. 13-20. Szpila G., 2003, Krótko o przystowiu, Kraków.

Świerczyńska D., 1974, O kilku gatunkach przysłów. Welleryzmy, dialogi, priamele, „Literatura Ludowa” nr 4-5 (18), s. 29-35.

Świerkosz A., 1930, Z wybrzė̇a polskiego: Hel. Zarys monograficzny z ilustracjami, Puck.

Treder J., 1986, Ze studiów nad frazeologia kaszubska (na tle porównawczym), Gdańsk. Treder J., 2000, Kaszubi. Wierzenia i twórczość. Ze Stownika Sychty, Gdańsk.

Treder J., 2006a, Ceynowy i Mosbacha „Wiadomość o Kaszubach” z połowy XIX w., w: A. Mosbach, Wiadomość o Kaszubach, Gdynia, s. 63-68.

Treder J. (red.), 2006b, Język kaszubski. Poradnik encyklopedyczny, Gdańsk. 